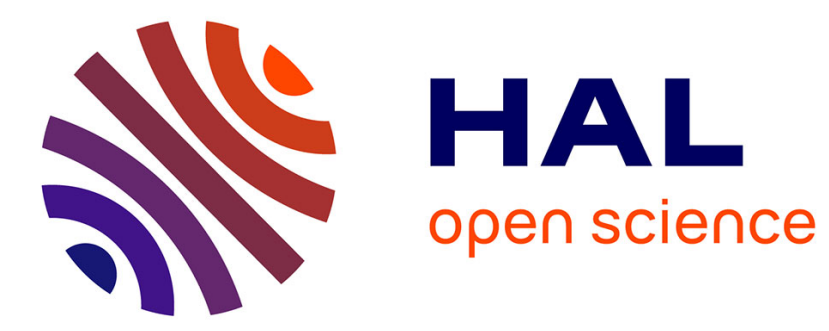

\title{
Evaluation of academic legal publications in France
}

Delphine Costa, Rob van Gestel, Andreas Lienhard

\section{To cite this version:}

Delphine Costa, Rob van Gestel, Andreas Lienhard. Evaluation of academic legal publications in France. Evaluating Academic Legal Research in Europe. The Advantage of Legging Behind, Edward Elgar Publishing, pp. 265-293 [29 p.], 2019, 9781788115490. hal-01997433

\section{HAL Id: hal-01997433 https://hal-amu.archives-ouvertes.fr/hal-01997433}

Submitted on 3 May 2019

HAL is a multi-disciplinary open access archive for the deposit and dissemination of scientific research documents, whether they are published or not. The documents may come from teaching and research institutions in France or abroad, or from public or private research centers.
L'archive ouverte pluridisciplinaire HAL, est destinée au dépôt et à la diffusion de documents scientifiques de niveau recherche, publiés ou non, émanant des établissements d'enseignement et de recherche français ou étrangers, des laboratoires publics ou privés. 


\section{Evaluation of academic legal publications in France}

\section{Delphine Costa}

\section{INTRODUCTION}

The introductory section of this chapter presents the institutional environment surrounding the different practices of academic research evaluation in law. After an outline of law schools in France (section 1.1), university financing is explained (section 1.2) and the authority responsible for evaluating higher education and research in France introduced (section 1.3). The process of evaluating research nationally is then addressed (section 1.4), before the absence of any ranking of academic legal journals is discussed (section 1.5).

\subsection{Law schools in France}

Since the Law of 12 November 1968 was introduced, ${ }^{1}$ there have been no more facultés in France, but only universities, ${ }^{2}$ which are public administrative institutions - in other words, legal entities governed by public law. Universities are home to education and research units, departments, research laboratories and centres and so on, all created by deliberation of the university council on advice from the academic council. ${ }^{3}$ However, the term 'faculte' has survived in some disciplines, such as law and medicine. ${ }^{4}$ There are currently 64 education and research units for law, bearing a range of names (e.g. 'faculty of law

1 Loi $n^{\circ}$ 68-978 du 12 novembre 1968 dite Edgar Faure d'orientation de l'enseignement supérieur 1968 10579; Maxime Renaudie, 'Entre critique juridique et critique du droit. Retour sur l'analyse doctrinale des réformes universitaires françaises' 2016 Revue de la recherche juridique - Droit prospectif 13.

2 Faculties were specific to medicine, law, literature and sciences; in contrast, universities are general to all academic fields.

3 Code de l'éducation art L 713-1.

4 A conference of deans of law and political science maintains among its traditions the reference to facultés. 
and political science', 'faculty of law and economics', 'department of legal, political and economic science', 'school of law'). ${ }^{5}$ The 2007 Act on university freedom and responsibility and the 2013 Act on higher education and research bolstered university autonomy, but did not bring back facultés. ${ }^{6}$ This autonomy is reflected above all in the transfer of management of the wages of academics from the central government to the universities, although teaching and research staff remain state employees. ${ }^{7}$ Accordingly, university funding is still largely dependent on central government (section 1.2.).

\subsection{University funding}

University funding is governed by rules that have become more complex since the above-mentioned 2007 legislation came into force in 2009. University budgets are determined on the basis of five-year contracts between the university and the government as a result of a negotiation process based on a periodic evaluation of the institutions. ${ }^{8}$ While part of the university budget is still based, as before, on quantitative criteria (e.g. student numbers, number of teaching research staff who publish), another part is negotiated on the basis of the university's qualitative performance criteria - for example, teaching to student pass rates and the evaluation of research centres (see below).

Due to their increased autonomy, universities can spread their sources of research funding. Although nationally set registration fees ${ }^{9}$ bring in little income, universities may secure funding by providing in-service training (e.g. to practitioners, career changers or the unemployed) and other services, or from research contracts and donations to funds they may set up. Still, some 80 per cent of university budgets come from the central government. ${ }^{10}$ Moreover, quantitative cri-

5 'Portail universitaire $d u$ droit', accessed March 2017 at https://univ-droit.fr/ facultes-de-droit.

$6 \quad$ Loi $n^{\circ} 2007-1199$ du 10 août 2007 relative aux libertés et responsabilités des universités 2007 13468; Loi $n^{\circ}$ 2013-660 du 22 juillet 2013 relative à l'enseignement supérieur et à la recherche 201312235.

7 France has not just universities, but also research institutions such as the Centre national de la recherche scientifique, the Institut national de la santé et de la recherche médicale and the Institut national de la recherche agronomique. However, legal science is little represented in these institutions, which are also subject to evaluation processes, the details of which are not further discussed in this chapter.

8 An evaluation is undertaken by HCERES (see section 1.3.) each five-year period, before the negotiation process between the universities and the government.

9 Arrêté du 31 juillet 2012 fixant les taux des droits de scolarité dans les établissements publics d'enseignement supérieur relevant du ministère de l'enseignement supérieur et de la recherche 201213056.

10 P Balme et al, L'université française: une nouvelle autonomie, un nouveau management (Presses universitaires de Grenoble 2012) 319. 
teria account for 80 per cent of this subsidy, as against 20 per cent for qualitative criteria, three-quarters of which results from research performance. Evaluation of research according to these criteria is therefore crucial for university funding.

\subsection{The evaluating authority}

All aspects of universities - teaching, research, governance - are evaluated by an independent administrative authority, the High Council for Evaluation of Research and Higher Education (Haut conseil de l'évaluation de la recherche et de l'enseignement supérieur (HCERES)), ${ }^{11}$ in successive waves before contracts are negotiated between the universities and the government. ${ }^{12}$ HCERES was created by decree in 2014; it has taken over the functions previously conferred on another independent administrative authority, the Agence d'évaluation de la recherche et de l'enseignement supérieur (AERES) set up in 2006. ${ }^{13}$

As its 2015 activity report states:

HCERES is governed by the principles of objective, transparent, collegial and independent evaluation, ensuring equal treatment for all evaluated entities. In order to guarantee compliance with these principles, tools such as the evaluation charter and the declaration concerning avoidance of conflicts of interest are used. HCERES evaluations are not prescriptive and do not lead to an official decision. They are designed to help universities conduct substantiated analysis, make informed decisions and define ways to make improvements. ${ }^{14}$

More specifically, on evaluating research units, HCERES considers that:

$[R]$ esearch shall be evaluated on the basis of multiple criteria in line with the approach defined by the HCERES which appraises scientific output and quality, academic influence and attractiveness, interaction with the social, economic and cultural environment, the entity's organization and activity, involvement in education through research, strategy and the five-year contract (see before). ${ }^{15}$

11 Décret $n^{\circ}$ 2014-1365 du 14 novembre 2014 relatif à l'organisation et au fonctionnement du Haut Conseil de l'évaluation de la recherche et de l'enseignement supérieur 2014 19308; Loi $n^{\circ}$ 2013-660 du 22 juillet 2013 relative à l'enseignement supérieur et à la recherche (n 5).

12 For example, if a university is evaluated by HCERES in the academic year 2016-2017, the contract with the central government will cover the period 2018-2022. Accordingly, there are five waves of evaluation and contract formation.

13 Loi de programme $n^{\circ}$ 2006-450 du 18 avril 2006 pour la recherche 20065820.

14 HCERES, 'Rapport d'activité 2015', accessed May 2017 at https://fr.calameo .com/read/0041019644042a70521b1.

15 HCERES, 'Dossier d'évaluation des entités de recherche', accessed May 2017 at www.hceres.fr/content/download/25698/397651/file/Livret\%20Global\%20Entit\%C3 $\% A 9 s \% 20 d e \% 20$ Recherche.pdf. 
These various items correspond to the evaluation criteria for research units and, through them, for teaching and research staff - especially by way of their academic output.

\subsection{The national process of research evaluation}

The evaluation of the activities of universities covers doctoral education, accreditation of institutions and multi-annual contracts, as provided for by the Education Code (Part Three - Forms of Higher Education: Article L612-7 s; Article L613-1 s; Article L711-1 s.).

More specifically, the Research Code provides that: 'Research activities funded in part or full from the public purse and performed by public- or private-sector operators, shall be evaluated on the basis of objective criteria adapted to each activity and grounded in international best practices. ${ }^{16}$ Among the objective evaluation criteria, it is stated that contributions to the development of 'scientific culture' 17 'and actions to promote public participation in prospection, data collection and the advancement of scientific knowledge shall be taken into account'. In other words, no reference is made to any specific method for evaluating scholarship, either quantitatively or qualitatively. In fact, the national process of research evaluation is imprecisely based on international best practices.

\subsection{The absence of any ranking of law journals}

Law journals, whether published in French or in a foreign language, are not ranked by quality. In 2010 a list of journals dealing with the field of law mostly legal journals, but also sometimes political, philosophical or historical journals - was drawn up in 2010 by AERES, predecessor of HCERES. The list merely enumerated the journals without ranking them - or even distinguishing between academic journals and those aimed at the legal profession. The AERES list is no longer available online - probably because it lacked any relevance, since it collated journal titles without ranking them in any way. ${ }^{18}$ In the absence of any qualitative ranking of all legal journals, it is difficult to evaluate legal publications in the context of an overall assessment of higher education and research institutions.

16 Code de la recherche - art L114-1 (Code de la recherche); Loi de programme $n^{\circ}$ 2006-450 du 18 avril 2006 pour la recherche (n 11) art 9.I.2.

17 Loi $n^{\circ}$ 2013-660 du 22 juillet 2013 relative à l'enseignement supérieur et à la recherche (n 5).

18 Geneviève Koubi, 'Liste de revues droit au sens de l'AERES... sans mention "scientifique",, accessed May 2017 at https://koubi.fr/spip.php?article472. 


\section{EVALUATION OF ACADEMIC LEGAL PUBLICATIONS FOR ASSESSMENT OF RESEARCH INSTITUTIONS}

Research centres are evaluated for each university at the time of its five-year review by HCERES (every university is evaluated separately). Teaching research staff are not evaluated individually, but only as part of the evaluation of the centre to which they are attached. Legal publications are therefore evaluated collectively for each research centre. The assessment is mediated by the evaluation of the research centres themselves: all legal publications of each research centre are collectively assessed. If the 'career monitoring' procedure were to be followed in France, then the various activities of teaching research personne $\mathrm{l}^{19}$ would be evaluated by some other body than HCERES. In fact, it is the National Council of Universities (Conseil national des universités (CNU)) that is responsible for evaluating teaching research staff (see section 6). Currently, HCERES examines legal publications when appraising the research centres by a specific method (section 2.1). It uses peer review to evaluate the performance of research centres (section 2.2) on the basis of explicit evaluation criteria (section 2.3), some of which focus on academic publications (2.4).

\subsection{The HCERES method for evaluating research entities}

HCERES evaluates higher educational institutions by segmenting its appraisals. Whereas degree courses are evaluated on paper alone, research centres, doctoral education and institutions are appraised based on reports submitted beforehand by committees that visit the research entity to meet the teaching research staff, administrative personnel and students.

In evaluating research entities, HCERES adopts a method which is described in a working document that can be accessed online. ${ }^{20}$ The evaluation rests on the following principles:

- 'a collective qualitative peer evaluation';

- 'an evaluation which, based on specific criteria, takes into account the variety of the entity's missions'; and

- 'an evaluation which, for each criterion, is based on observable facts and results in a qualitative assessment'.

19 In France, each researcher is also a teacher: activities in both researching and teaching are evaluated together.

20 HCERES, 'Critères d'évaluation des entités de recherche, Le référentiel, accessed May 2017 at www.hceres.fr/MODALITES-D-EVALUATIONS/Campagne -d-evaluation-2016-2017/Evaluations-des-entites-de-recherche. HCERES, 'Criteria for 
The results of the HCERES evaluation are described in a public report.

Before explaining these principles, a brief description must first be given of how the evaluation is conducted. On the basis of a dossier completed by the research entity with the university's assent, a peer committee visits the research entity and meets the management, the teacher-researchers, the administrative personnel and the students (especially doctoral students). The dossier first sets out the unit's scientific policy and then its achievements (e.g. academic output and influence of the entity, determined by the organization of congress). Next, the unit's involvement in education via research is outlined; and finally the prospects for the research entity are described. ${ }^{21}$ This dossier is supplemented with figures indicating the number of teacher-researchers, doctoral students, publications and so on. The site visit and the meetings with the main interested parties ensure that the documents sent to HCERES are a true reflection of the research entity's academic practice.

After the visit, the committee drafts a report indicating the research entity's strengths and weaknesses and issuing an assessment, to which the research entity may respond. It is this assessment that counts as the qualitative review of the research entity.

\subsection{Qualitative peer evaluation}

Clearly, HCERES has chosen peer review rather than performance metrics, which are considered inappropriate for many academic disciplines, notably by the Academy of Science. ${ }^{22}$ HCERES considers that 'the quality of activities, outputs and results cannot be reduced to quantitative elements'.$^{23}$ It adds that '[v]alue or quality should be based on observable facts, including quantitative data, through analysis, discussion and interpretation taking into account the entities' context' ${ }^{24}$ True, the qualitative evaluation does not exclude resort to quantified elements; but these are only one element among others. This is why the expert committee that visits a research entity bases its review on figures

the evaluation of research units: The HCERES standards', accessed May 2017 at www .hceres.fr/MODALITES-D-EVALUATIONS/Campagne-d-evaluation-2016-2017/ Evaluations-des-entites-de-recherche.

21 HCERES, 'Dossier d'évaluation des entités de recherche', accessed May 2017 at www.hceres.fr/content/download/25698/397651/file/Livret\%20Global\%20Entit\%C3 $\%$ A9s\%20de\%20Recherche.pdf.

22 Académie des sciences, 'Du bon usage de la bibliométrie pour l'évaluation individuelle des chercheurs' (2011), accessed May 2017 at www.academie-sciences.fr/pdf/ rapport/avis170111.pdf.

${ }^{23}$ HCERES, 'Critères d'évaluation des entités de recherche, Le référentiel' (n 17)

9. 'Criteria for the evaluation of research units: The HCERES standards' (n 17) 5.

24 Ibid. 
communicated by the entity, especially regarding the number of academic publications. Generally, the committee takes account of the environment and the nature of the research entity in its evaluation. It uses objective criteria to do this. The committee, with a different composition for each entity, thus undertakes an independent and transparent review.

\subsection{The explicit criteria for review}

HCERES has used six evaluation criteria since $2012:^{25}$

- scientific production and quality;

- academic reputation and appeal;

- interaction with the social, economic and cultural environment;

- organization and life of the research entity;

- involvement in training through research; and

- strategy and research perspectives for the next five years.

In addition, HCERES explains how each 'evaluation criterion closely relates factual data that can be observed by reviewers to support their assessment (observable facts like number of publications or organisation of congress) and the value to accord to those data to come up with the evaluation proper (quality indices)', because some facts are more important than others. ${ }^{26}$ HCERES specifies that three operations are performed for each evaluation criterion:

1. Determine the field covered by the criterion;

2. Specify the observable facts; and

3. Compare and contrast that data with consensus-based quality indicators for the discipline, which will depend on the relevant academic discipline. ${ }^{27}$

Besides, HCERES recalls that 'quantitative indicators. . . can only act as an aid in the peer review process'.$^{28}$ Each criterion gives rise to a synthetic textual assessment rather than a mark, so as to enlighten the research entities as to their strengths and weaknesses. Review is therefore meant to improve the research entities.

Ibid 7.

Ibid 8. French version only.

Ibid 8-9.

Ibid 9 


\subsection{Review criteria specific to scientific output}

HCERES gives details of the scientific production criterion - specifying that its field of application concerns the scientific results of a research entity compared with the standards in the discipline - which are shared by the experts who are members of a committee. ${ }^{29}$ It then mentions the factual data and the quality indicators with which to assess the scientific output criterion.

On the one hand, the observable facts are: ${ }^{30}$

1. Scientific publications (e.g. books, book chapters, critical editions of texts, translations, articles in peer-reviewed journals, conference proceedings);

2. Lectures (e.g. oral presentations to conferences without published proceedings, conference posters, invited lectures, sets of slides); and

3. Other scientific output specific to the field (e.g. scientific reports).

On the other hand, the quality indicators are: 'the originality and results of research, the importance of discoveries to the relevant field; theoretical and methodological breakthroughs, paradigm shifts, emergence of new problems or new avenues of investigations; the scientific impact within academia (citations, references, etc.); international or national recognition; the reputation and selectivity of the journals, etc.' ${ }^{31}$

On reading these clarifications, it may be observed that the criterion for evaluating scientific output is indeed qualitative, but that it calls on quantitative data when it comes to counting the number of publications or putting a figure on their impact. However, citations and references are not measured in France; the number of publications can be only counted.

HCERES evaluation is very important for research units, because it determines in part the funding of their activities within the university in which they are based. However, it is not a question of evaluating the teaching research staff themselves.

\section{EVALUATION OF LEGAL PUBLICATIONS ON SUBMISSION TO A PUBLISHER}

In France, there is no uniform practice for evaluating scientific output in the field of law prior to publication. In other words, the assessment depends on the publications and publishers; it also depends on publication form (i.e. journals or books). Schematically, traditional law journals adopt an editorial policy

\footnotetext{
Ibid 10

Ibid 11 .

Ibid.
} 
specific to them (section 3.1); whereas other often more recent, sometimes digital, law journals are moving towards peer review (section 3.2). For books, the evaluation depends mainly on editorial policy, which differs depending on the type of book (section 3.3). A few prospects are then outlined (section 3.4).

\subsection{Editorial review of law journals}

Although it is not easy to determine this exhaustively, traditional law journals seem to follow an editorial policy specific to them. Looking at the major publishing firms in the field of law - Dalloz, Lextenso and LexisNexis - it may be observed that each journal comes under the scientific responsibility of an academic editor and the publishing responsibility of an editor in chief. For some law journals, there is also a scientific committee, a review committee and/or an editorial committee.

Most journals provide guidelines for contributors that can be easily found in the print version and sometimes online too. For example, the Revue trimestrielle de droit européen, published by Dalloz, specifies that proposals are submitted to a review committee which gives its answer within six weeks, during which time the author undertakes not to submit the proposal to any other journal. ${ }^{32}$ Logically, the submission states the author's name, title, position and contact details. The guidelines are formal and include no quality criteria, as illustrated by another memo for authors by journal Actualité juridique - droit administratif. ${ }^{33}$ However, not all law journals necessarily adopt such an opaque editorial policy - even if most law journals in France are not peer reviewed and have no explicit quality criteria listed in their submission guidelines.

\subsection{Towards peer review of law journals}

Some law reviews use peer review by review committees, to which the contributors remain anonymous. The Revue trimestrielle des droits de l'homme $(R T D H)$, published in Belgium, clearly states that proposals - which must comply with certain formal requirements - are submitted to "the editorial committee or scientific committee, which make their selection depending on the scientific quality of the submissions', as determined by the strength of the legal argumentation. ${ }^{34}$ It is then stated that 'the main readers appraise

32 Dalloz, 'Note à l'attention des auteurs', accessed May 2017 at www.dalloz -revues.fr/auteurs/rtdeur-auteurs.html.

33 Dalloz, 'Note à l'attention des auteurs' [2016] AJDA 1985.

34 RTDH, 'Note à l'attention des auteurs', accessed May 2017 at http://rtdh.eu/pdf/ consignes20140625.pdf. 
the text without being informed of the author's name', ${ }^{35}$ which ensures an impartial review. In addition, the $R T D H$ sets out certain selection criteria for articles proposed: 'the interest of the subject treated, in relation with the object of the review, its originality and the scientific rigour', as well as 'their cross-disciplinary character' ${ }^{36}$ Review by the $R T D H$, published by Nemesis (Brussels, Belgium), therefore proves virtuous, especially because it is 'blind' and based on scientific criteria such as scientific rigour (which is demonstrated by a clear methodology and strong arguments).

Still in the realm of human rights, recent French journals have also adopted a policy of peer review. Two illustrations of digital journals can be given. ${ }^{37}$

The Revue des droits et libertés fondamentaux is a digital review which has a 'Contribute' tab providing advice for authors who would like to submit a proposal to the journal's editorial board. It states notably that 'Articles proposed to the journal are submitted to a review board of three academics drawn from the journal's editorial board depending on the subject matter'. ${ }^{38}$ The editorial board is made up of numerous teacher-researchers. However, it is not specified whether the review board works blind or what criteria it uses.

The Revue des droits de l'homme is also digitally published by a teacher-researcher collective. It undertakes a double-blind review of papers. The journal specifies that "contributions will be reviewed anonymously by two reviewers from the scientific committee (or external reviewers if necessary, when the subject is very specific) appointed by the editor-in-chief of the La RevDH' ${ }^{39}$ However, it gives no more clarification than the previous journal about the scientific criteria for reviewing proposals; nor does it disclose statistics about the acceptance rate of proposals any more than the previous journal.

However, these illustrations show that peer review is becoming more common for publishing articles in specialized journals. The same is not true for books.

\subsection{Editorial policy for publication of law books}

The editorial policy for specialist books in the discipline of law is specific to each publisher. Each publisher has its specificities: for example, LexisNexis

35 Ibid.

36 Ibid. See also the review Droit \& Société, accessed May 2017 at http://ds .hypotheses.org/recommandations-aux-auteurs.

37 See also www.juspoliticum.fr, accessed December 2017.

38 RDLF, 'Contribuer', accessed May 2017 at www.revuedlf.com/contribuer.

39 RevDH, 'Soumettre une contribution', accessed May 2017 at http://revdh.revues .org/265. 
SA belongs to an international holding company, RELX Group, ${ }^{40}$ meaning that its editorial policy is very much influenced by economic development. Accordingly, it relies mainly on its digital activities. In addition, it publishes journals as well as academic, professional and scientific books. However, guidelines are given to authors wishing to propose a book. They therefore contact the publisher directly, who reserves the decision to publish, with no evaluation criterion being disclosed. This is critical, because nobody knows what is expected by the publisher.

Some law books, however, undergo prior evaluation in the form of a 'competition': these are $\mathrm{PhD}$ theses for which publication by a prestigious publisher is an award. Several illustrations can be given of the editorial policy for publishing doctoral theses.

The Librairie générale de droit et de jurisprudence (LGDJ) - a publisher that now belongs to a public company, Lextenso éditions - has published collections of theses for many years in its 'Bibliothèque de droit privé', 'Bibliothèque de droit public', 'Bibliothèque de sciences criminelles', 'Bibliothèque de droit social' and so on. Arrangements for applying for publication are posted on the LGDJ website. ${ }^{41}$ Candidates must send the publisher a copy of the thesis, a $\mathrm{CV}$, a letter of motivation from the candidate, a letter of support from the supervisor, the report on the viva exam and any other relevant documents (e.g. thesis award). It is then stated that 'after reviewing the thesis and the application, the editor of each collection decides whether or not to accept to publish it'. ${ }^{42}$ The collection editors are presented on the website. In addition, for two of its collections - 'Bibliothèque de droit privé' and 'Bibliothèque de sciences criminelles' - a specific selection procedure has been put in place: a selection committee, chaired by the collection editor(s) meets twice a year to draw up the list of theses that will be published. However, candidates are not told of the composition of these committees.

Dalloz has had a collection for more than a decade titled 'Nouvelle Bibliothèque de Thèses', which publishes ten $\mathrm{PhD}$ theses a year in public and private law and three in political science, selected by competition. ${ }^{43}$ Candidates must send publishers a copy of their thesis, a CV, the viva exam report and, if necessary, a letter from the supervisor. Only after selection are candidates told who the panel members are, to preserve impartiality.

40 RELX Group, 'About us', accessed May 2017 at www.relx.com/AboutUs/Pages/ Home.aspx.

41 LGDJ, 'Vous souhaitez publier votre thèse?', accessed May 2017 at www lextenso-editions.fr/doctorants.

42 Ibid.

43 Dalloz, 'Publication - Nouvelle Bibliothèque des Thèses', accessed May 2017 at www.editions-dalloz.fr/media/upload doc cms/bibliotheque8.html. 
Lastly, a recently established publisher, Mare \& Martin, edits several collections in law, including a 'Bibliothèque des Thèses'. There is a scientific committee for the law and political science collections ${ }^{44}$ and two editors for the thesis collection..$^{45}$ The editors review each manuscript proposed in conjunction with the members of the scientific committee. The editorial policy is set out clearly: 'All the titles are edited with great care and include a full scholarly and critical apparatus that make these books essential tools for those wanting to supplement their knowledge or discover new lines of research. ${ }^{46}$ In addition, some criteria are indirectly disclosed to the authors in the presentation that the editors make of their editorial choices: 'Intellectual rigour, multidisciplinarity, aestheticism and originality are the characteristics of the books proposed in different areas of knowledge, with an editorial view to abide as closely as possible to the author's thought and meet readers' legitimate expectations as to quality. ${ }^{47}$ Although virtuous and demanding, this editorial policy still lacks transparency with regard to the evaluation process of law book publications, whether doctoral theses or other monographs.

In short, the evaluation of law books often remains dependent on each publisher's editorial policy, with constraints that are sometimes more economic than scientific.

\subsection{Prospects}

Two sets of prospects can be put forward. It would be helpful if the selection procedures that are beginning to develop for some law journals and for the publication of doctoral theses were extended to all journals and books. This would make peer review the standard procedure for selection of publications in law. The young generation supports this evolution.

It would also be helpful to make public to potential authors, before articles and books are selected, the qualitative scientific criteria based on which reviews are conducted. These criteria generally remain implicit, even for journals and collections that are currently peer reviewed. This is still the case for the evaluation of doctoral research work.

44 Mare \& Martin, 'Comité scientifique "Droit et Science politique",, accessed May 2017 at www.mareetmartin.com/comite-scientifique-droit-science-politique.

45 Mare \& Martin, 'Collection Bibliothèque des Thèses', accessed May 2017 at www.mareetmartin.com/collection-bibliotheque-des-theses.

46 Mare \& Martin, 'Les Éditions Mare \& Martin', accessed May 2017 at www .mareetmartin.com/les-editions-mare-et-martin.

47 Ibid. 


\section{EVALUATION OF DOCTORAL THESES}

The doctoral thesis in law is ambivalent to some extent: while it is essential for an academic career, it is also encouraged in all professional areas of law. A legislative provision states that for attorney education: 'Doctors of law have direct access to the theoretical and practical education and training. . . without having to sit the entrance examination to the regional centre for professional education and training of attorneys. ${ }^{48}$ Doctoral studies were the subject of a 2016 reform emphasizing the need to abide by scientific criteria at every stage of doctoral research (section 4.1). In addition, for doctors of law looking to enter academia, scientific evaluation is particularly demanding (section 4.2). For the latter, the statistical data is rather discouraging (section 4.3).

\subsection{Evaluation of doctoral theses during doctoral studies}

It is now an order of 25 May 2016 that sets out the national framework for education and the conditions for awarding the national doctoral diploma (hereafter, the 2016 order).$^{49}$ Scholarly requirements are made of doctoral students at each stage of their doctoral education.

The doctoral degree is prepared in doctoral schools under the responsibility of universities and within a research entity (Article 10 of the 2016 order). Like universities and research entities, doctoral schools are evaluated every five years by HCERES. To register for a doctoral course, candidates must have a master's degree (or equivalent). In terms of evaluating candidates' scholarly qualities, Article 11 of the order provides that: 'At the time of the annual registration for the doctoral course, the school director checks that the scientific, material and financial conditions are right to ensure the student's research work and thesis preparation go successfully.' Furthermore, 'registration is renewed at the beginning of each academic year by the head of the institution upon proposal from the director of the doctoral school, after receiving the opinion from the thesis supervisor and, from the third registration onward, the doctoral student's individual monitoring committee'.

In practice, the scientific quality of the doctoral research work is appraised more by the thesis supervisor than by the head of the institution or the director of the doctoral school. Moreover, the doctoral student's individual moni-

48 Loi $n^{\circ} 71-1130$ du 31 décembre 1971 portant réforme de certaines professions judiciaires et juridiques JORF du 5 janvier 1972 131, art n 12-1.

49 Arrêté du 25 mai 2016 fixant le cadre national de la formation et les modalités conduisant à la délivrance du diplôme national de doctorat JORF $n^{\circ} 0122$ du $27 \mathrm{mai}$ 2016; David Deroussin, 'Réforme Du Doctorat: Quelles Perspectives? 
toring committee, introduced in 2016, which meets annually from the third year of thesis registration, must be able to ensure that the scientific quality is maintained. It is stipulated that 'an individual monitoring committee for the doctoral student ensures the course of study goes successfully' and 'evaluates, in an interview with the doctoral student, the conditions of their education and the advancement of their research' (Article 13 of the 2016 order). However, the committee, composed by the director of the research centre, is meant above all to ensure that the doctoral student works correctly, and the thesis supervisor does not sit on the committee; 'in particular the committee is careful to prevent any form of conflict, discrimination or harassment' (ibid). The practice of these committees may vary from one doctoral school to another, which precludes the committees from being seen as instruments for evaluating the scientific quality of doctoral research, particularly as the innovation is still very recent.

Finally, it is at the end of the thesis that its scientific quality is evaluated, when it is publicly defended in an oral examination. Article 17 of the 2016 order specifies that: 'Authorization to defend a thesis is granted by the head of the institution on receiving the opinion of the director of the doctoral school, upon proposal from the thesis supervisor'. The authorization is given after submission of their report by two reviewers from outside the doctoral school, 'designated by the head of the institution. . . upon proposal from the director of the doctoral school, after receiving the opinion of the thesis supervisor' (ibid). If the oral examination is authorized, the examining board - made up of four to eight members - will meet. The board includes the thesis supervisor, but he or she does not take part in the final deliberation. Article 19 of the 2016 order provides that: 'In its deliberations the board appraises the quality of the doctoral candidate's work, its innovative character, the candidate's aptitude to situate it in its scientific context and the quality of the exposition.' Accordingly, the oral examination is when the scientific qualities of the thesis are evaluated by academics who were not involved in its development and who are considered to act impartially.

Although the 2016 order is still recent, it has not radically changed the organization of doctoral studies. Above all, it is difficult to determine whether the scientific quality of doctoral candidates is sufficiently high to lead to satisfactory professional activity (section 4.3). For academic careers, the evaluation of doctoral research can be examined during the procedure for qualifying doctors for teacher-researcher positions (section 4. 2).

\subsection{Evaluation of doctoral theses in the perspective of an academic career}

Doctors seeking a career in academia must be qualified for the position of associate professor by a division of the CNU. This procedure is a necessary 
precondition to recruitment by a university. The CNU is a national instance 'that rules. . . on individual measures relating to qualification, recruitment and the career of full and associate professors' as provided for by the decree of 16 January 1992 (art. $\left.{ }^{\text {er }}\right){ }^{50}$ The CNU 'is composed of groups, themselves subdivided into divisions, each corresponding to a discipline' (Article 2). Law counts three divisions: private law and criminal sciences (Division 01), public law (Division 02) and the history of law and institutions (Division 03). These divisions develop an annual activity report that provides valuable information on the methodology adopted for evaluating doctors' research work at the time of the procedure for qualification for associate professor positions. ${ }^{51}$ Moreover, the $\mathrm{CNU}$ divisions advise applicants of personal recommendations ${ }^{52}$ which state the qualitative criteria on which their research work shall then be evaluated for undertaking an academic career. All applicants can use these recommendations to improve their research work within the optics of a further academic career.

Logically, the evaluation criteria are the same in the activity reports and the recommendations to applicants. The private law division examines the research work, particularly the $\mathrm{PhD}$ thesis,${ }^{53}$ using the following criteria:

- the interest of the subject pertaining to its originality, its nature and its juridical purpose;

- exhaustive and controlled processing of the data available on the subject matter;

- faultless notes and editorial comment;

- formal qualities of presentation and clarity; and

- substantive qualities by which to identify a genuine thesis, which presupposes a scientific, objective, reasoned and critical approach providing new

50 Décret $n^{\circ} 92-70$ du 16 janvier 1992 relatif au Conseil national des universités JORF $n^{\circ} 18$ du 22 janvier 19921034.

${ }_{51} \mathrm{CNU}$, section 01 (droit privé), 'Rapports d'activités et documents' accessed May 2017 at www.cpcnu.fr/web/cnu-section-01/rapport-d-activites-et-documents; CNU, section 02 (droit public), 'Rapports d'activités et documents', accessed May 2017 at www.cpcnu.fr/web/cnu-section-02/rapport-d-activites-et-documents; CNU, section 03 (histoire du droit), 'Rapports d'activités et documents', accessed May 2017 at www .cpcnu.fr/web/cnu-section-03/rapport-d-activites-et-documents.

$52 \mathrm{CNU}$, section 01 (droit privé), 'Recommandation MCF - Portail', accessed May 2017 at www.cpcnu.fr/web/cnu-section-01/recommandation-mcf; CNU, section 02 (droit public), 'Recommandation MCF - Portail', accessed May 2017 at www.cpenu .fr/web/cnu-section-02/recommandation-mcf; CNU, section 03 (histoire du droit), 'Recommandation MCF - Portail', accessed May 2017 www.cpcnu.fr/web/cnu-section -03/recommandation-mcf.

53 CNU, section 01 (droit privé) (n 48): 'Pour apprécier l'aptitude du candidat à contribuer à la recherche, l'évaluation porte d'abord sur la thèse du candidate.' 
points of knowledge, explanation and - above all - an understanding of the subject and its subject area.

The most important criterion for the private law division is to ensure the character, authentically and scientifically argued, of the applicant's research work, according to the body of knowledge.

Likewise, the public law division takes into consideration the work of the applicant, especially the thesis, ${ }^{54}$ considering:

- the interest of the subject, pertaining especially to its originality and its nature;

- exhaustive and controlled processing of the data available on the subject;

- the formal qualities; and

- the scientific approach (the demonstration must be ordered, reasoned, critical, honest and provide knowledge, explanation and - above all - an understanding of the subject matter).

And in the same way, the history of law division is most attentive to "the subject matter of the thesis or equivalent monograph and particularly the methodology of the historian-lawyer: the choice of sources, their treatment, understanding of the institutions and legal concepts'. ${ }^{55}$ It adds that it 'evaluates the applicant's ability to identify an issue, construct an argument and reason analytically', ${ }^{56}$

Experience ${ }^{57}$ shows that the scientific quality of the $\mathrm{PhD}$ thesis is the decisive component in qualifying for positions of associate professor. In other words, review by peers sitting in the CNU divisions is used to identify those doctors who deserve to pursue an academic career. The $\mathrm{PhD}$ thesis in law, then, is the subject of quite stringent criticism, as certain statistical data attests (section 4.3).

\subsection{Statistical data}

Generally, in March 2016 the organization that audits public accounts, the Cour des comptes, presented a rather alarming report on the professional integration of doctors in France in a response to the minister of education and

54 CNU, section 02 (droit public) (n 48): 'La thèse est en principe l'élément essentiel à prendre en considération.'

55 CNU, section 03 (histoire du droit) (n 48).

56 Ibid.

57 The author is participating in CNU section 02 for the period 2015-2019 as a substitute member appointed by the minister for higher education and research: décret $n^{\circ} 92-70$ du 16 janvier 1992 relatif au Conseil national des universités (n 46), art 4.II. 
higher education. ${ }^{58}$ In particular, the Cour des comptes observed that, taking all disciplines together (except for healthcare), 'the unemployment rate of young doctors. . . three years after graduating was close to 9 per cent in 2009 '59 - that is, 'four to nine times higher than in other OECD countries that same year (2 per cent in the UK and 1 per cent in Japan)' ${ }^{60}$

Under closer scrutiny, the French Centre for Research on Education, Training and Employment has reported in a survey on the employment status of doctors qualified in 2010 by 2013 that in 'Law - Economics', more than half worked in public sector research. ${ }^{61}$ However, since the law sector is not separated from the economics sector, it is difficult to draw more precise conclusions.

In this regard, the activity reports of the law divisions of the CNU provide useful clarification. Looking at the figures for the different divisions, it seems that in recent years, about one in four applicants in private law and public law and one in three applicants in history of law qualified for lectureship positions. ${ }^{62}$ However, qualification does not mean recruitment (see section 6.1); moreover, some unlucky applicants in a year $\mathrm{N}$ may qualify in year $\mathrm{N}+1 \mathrm{~N}+2$, meaning that over several years, far more than one in four or one in three applicants may qualify. Concerning subsequent recruitment as associate professors, one of the reports establishes a proportion over two years of more than 70 per cent of recruitment among doctors qualified. ${ }^{63}$

Even in the absence of reliable quantitative data, these few indicators show that peer review of the scholarly qualities of $\mathrm{PhD}$ theses in law is extremely thorough.

58 Cour des comptes, 'L'insertion professionnelle des jeunes docteurs' (2016) Référé $n^{\circ} S$ 2015-1294; Laura Buratti, 'La Cour des comptes juge l'insertion professionnelle des docteurs décevante' Le Monde (23 March 2016), accessed May 2017 at www.lemonde.fr/campus/article/2016/03/23/la-cour-des-comptes-juge-le-taux-de -chomage-des-docteurs-decevant_4888742_4401467.html.

59 Cour des comptes (n 54) 3.

60 Ibid.

61 Centre d'études et de recherches sur les qualifications, 'L'insertion à trois ans des docteurs diplômés en 2010' (15 December 2015) 53, accessed May 2017 at www .cereq.fr/publications/Net.Doc/L-insertion-a-trois-ans-des-docteurs-diplomes-en-2010.

62 CNU, section 01 (droit privé) (n 47); CNU, section 02 (droit public) (n 47); CNU, section 03 (histoire du droit) (n 47).

63 CNU, section 02 (droit public) (n 47): v Rapport 2015_Section 02.pdf. 


\section{EVALUATION OF RESEARCH PROJECTS BY FUNDING AGENCIES}

Two types of institutions fund research projects in France: European and national institutions. Only the latter are described here, since they are specific to the French case. France has an institution for funding research on calls for projects: the National Research Agency (Agence nationale de la recherché (ANR)), set up in 2006. ${ }^{64}$ The ANR gives precedence to cross-disciplinary projects: it is difficult, therefore, to count the legal science projects among those funded by the ANR. Even so, it is useful to examine the ANR missions and operating principles (section 5.1), then briefly set out the procedures for selecting research projects (section 5.2). This cursory presentation shows that legal sciences receive very little national funding via the competitive selection procedures introduced by the ANR (section 5.3).

\subsection{The ANR's missions and operating principles}

The ANR's main mission is 'to implement research funding on projects in France' ${ }^{65}$ More specifically, the ANR 'endeavours to contribute to the development of science and technology; to promote creativity, decompartmentalization, emergence and partnerships; to target research efforts towards economic and societal priorities. . . ; to encourage interaction among disciplines; to intensify public-private linkages' ${ }^{66}$ To achieve these objectives, the ANR rolls out varied funding instruments for researchers and businesses; it also manages the major government investment programmes for higher education and research.

Moreover, the ANR operates in accordance with international standards in terms of research project funding. ${ }^{67}$ It adopts as its operating principles fair treatment, competitive selection, conflict of interest management, peer review by French and foreign experts from outside the agency. ${ }^{68}$ In a little over 10 years, the ANR has funded more than 13,000 projects.

64 Décret $n^{\circ}$ 2006-963 du $1^{\text {er }}$ août 2006 portant organisation et fonctionnement de l'Agence nationale de la recherche 2006 11567. It is now a public administrative institution - that is, a legal entity separate from the state.

65 'Missions de l'Agence Nationale de la Recherche', accessed May 2017 at www .agence-nationale-recherche.fr/missions-et-organisation/missions/.

66 Ibid.

67 Ibid: it complies with ISO 9001.

68 Ibid. 


\subsection{Overview of the ANR's research project selection procedures}

The main procedure is lengthy and complicated: each year there is a 'work programme' organized around four cross-cutting components, each with dedicated funding instruments. ${ }^{69}$ Each funding instrument is specific in its objectives and its selection and monitoring characteristics. Legal research may fit into one of these four components, which focus on nine major societal challenges:

1. Efficient resource management and adaptation to climate change;

2. Clean, secure and efficient energy;

3. Industrial renewal;

4. Life, health and wellbeing;

5. Food security and demographic challenges;

6. Sustainable mobility and urban systems;

7. Information and communication society;

8. Innovative, inclusive and adaptive societies; and

9. Freedom and security of Europe, its citizens and its residents..$^{70}$

The component devoted to these challenges for society is the subject of 'generic calls for projects'. It uses all the ANR funding instruments - in other words:

- collaborative projects in a national or international context (Collaborative Research Projects PRC and International Collaborative Research Projects PRCI);

- projects that engage with the business world (Collaborative Research Projects Involving Enterprises, PRCE); and

- individual research projects coordinated by young researchers (JCJC).

The generic calls for projects procedure unfolds in two stages: submission of a three-page preliminary proposal and then, if the response is positive, submission of the actual project. ${ }^{71}$ To examine the projects submitted to it, the ANR resorts to two types of external scientific personalities. It asks national and international experts to examine research projects and draw up a report on the basis of pre-established evaluation criteria. It also convenes evaluation

69 'Plan d'action 2017', accessed May 2017 at www.agence-nationale-recherche .fr/financer-votre-projet/plan-action-2017/.

70 'Composante "Grands défis sociétaux”, accessed May 2017 at www.agence -nationale-recherche.fr/financer-votre-projet/plan-action-2017/grands-defis-societaux/

71 'Appel à projets générique', accessed May 2017 at www.agence-nationale -recherche.fr/AAPG2017. 
committees that assign experts to projects and rank the projects on the basis of reports from the experts.

\subsection{Marginal funding of research projects in law by the ANR}

Faced with the complexity of ANR procedures, specialist research entities in legal sciences are often at a loss: they often lack dedicated staff to launch fundraising projects. From a quick text search, it appears that in 2016, out of 801 projects funded by the ANR, only two were mostly in law, giving a ratio of 0.25 per cent. ${ }^{72}$ Whatever the virtues of competitive selection, it does not seem to take precedence in the area of law.

Evaluation of law publications is very much more important when it comes to the careers of teacher-researchers.

\section{EVALUATION OF LAW PUBLICATIONS WITH RESPECT TO CAREERS OF TEACHER-RESEARCHERS}

Teacher-researchers' careers can develop nationally and/or locally. Evaluation of the scholarly publications of teacher-researchers is important, depending on their career stage: when they first take up a position (section 6.1), when they achieve professor status (section 6.2), for internal promotion (section 6.3) and even with respect to earnings, although they are government employees (section 6.4). Even so, this evaluation is not truly generalized (section 6.5).

\subsection{Starting on the teacher-researcher career ladder}

To start out on an academic career in all disciplines, holders of a doctorate may become associate professors (see section 4.2). There are two separate stages in becoming an associate professor: qualification by the CNU and recruitment by a university.

There is no need to review the procedure for qualifying for positions as associate professor in one of the three legal science divisions of the CNU. This procedure takes into consideration the publications of young doctors, especially

72 'Appel générique 2016: résultats au 21 juillet 2016', accessed May 2017 at www.agence-nationale-recherche.fr/suivi-bilan/plan-d-action-2016/resultats-appel-a -projets-generique. One project relates to the future of labour law and the other to rights access, care trajectories and appropriation of state medical aid in France. 
their doctoral thesis. However, the CNU qualification is not enough: the qualified doctor must still be recruited as an associate professor by a university. ${ }^{73}$

Each year, universities make public their vacant positions. These positions may be filled by first-time entrants or by associate professors who already have positions, but wish to transfer between institutions. ${ }^{74}$ The job profile published should set out the university's requirements in terms of teaching and research. The recruitment procedure is undertaken by a selection committee and takes place in two stages. ${ }^{75}$

The selection committee is designated by the board of administration of the recruiting university. It is made up of teacher-researchers of the same discipline as that which is open for competition. The composition of the committee must meet several requirements as to equality: at least half of the committee members must be from outside the recruiting university, so as to avoid conflicts of interest; and there must be equal numbers of associate and full professors, and equal numbers of men and women. ${ }^{76}$

The committee begins by examining all the applications received by the university. Each application is examined by two rapporteurs, complying with the requirements as to equality. When first convened, the committee listens to the rapporteurs, who give their opinion based on the application dossier. The committee then draws up a list of all applicants who correspond to the job profile and whom it wishes to interview.

Two weeks later, the committee meets again to interview the applicants it has selected. The rapporteurs will have read through the applicants' publications so as to evaluate the applications more closely. They will disclose their

73 Qualification for lectureships is valid for four years, during which the candidate may apply for positions at universities that are recruiting.

74 There are special dispensation procedures for the disabled and for applicants looking for a transfer closer to home: Décret $n^{\circ} 84-431$ du 6 juin 1984 fixant les dispositions statutaires communes applicables aux enseignants-chercheurs et portant statut particulier du corps des professeurs des universités et du corps des maîtres de conférences JORF 8 juin 1984 1784, art 9-3; Décret n²017-854 du 9 mai 2017 modifiant le décret $n^{\circ} 84-431$ du 6 juin 1984 modifié fixant les dispositions statutaires communes applicables aux enseignants-chercheurs et portant statut particulier du corps des professeurs des universités et du corps des maîtres de conférences JORF n॰0109 10 mai 2017; Loi $n^{\circ}$ 84-16 du 11 janvier 1984 portant dispositions statutaires relatives à la fonction publique de l'Etat JORF 12 janvier 1984 271, arts 60 and 62.

75 Fabrice Melleray, 'A la recherche des jurys de recrutement des enseignants-chercheurs' (2011) 10 Actualité Juridique Droit Administratif(AJDA) 539; Raphaël Romi, 'Les nouvelles modalités de recrutement des enseignants-chercheurs : une réforme à parfaire ?' (2009) 4 Actualité Juridique Droit Administratif (AJDA) 192.

76 Décret $n^{\circ} 84-431$ du 6 juin 1984 fixant les dispositions statutaires communes applicables aux enseignants-chercheurs et portant statut particulier du corps des professeurs des universités et du corps des maîtres de conférences (n 70) arts 9, 9-1, 9-2. 
opinions on the applicants before the interview proper. It is at this point that there is a qualitative peer review of the scholarly publications in law of the applicants convened for the committee's second meeting. At the interview, the applicants may be questioned by the committee members about their research. After the second meeting, the committee ranks the applicants in order and makes an offer accordingly; the applicant may accept or decline the position. The university academic council then recruits the successful applicant.

In short, evaluation of research is one of several components in the procedure for recruiting associate professors - above all, at the CNU qualification stage, but also to a lesser extent at the time of recruitment by universities.

Once an associate professor, the teacher-researcher may advance within the profession (section 6.3) or attempt to become a full professor (section 6.2). In both instances, more often than not, the qualitative assessment criteria of scholarly output will be taken into account.

\subsection{Access to professorships}

Access to the corps of university full professors has always been diverse. Above all, it differs in law from other disciplines - both the hard sciences and human and social sciences. The standard procedure for becoming a full professor in private law, public law and history of law is still a highly specific competitive examination: the agrégation du supérieur. ${ }^{77}$ However, there are other channels that are similar to the standard procedures for recruitment of teacher-researchers and that involve peer review.

Decried by some, lauded by others, the agrégation is a specificity of the French public sector. ${ }^{78}$ The competitive examination is held every other year

77 This competition was also the standard procedure in political science, economics and management, but in those disciplines it ended up disappearing or being radically changed. See Frédérique Pigeyre, 'Recruter les professeurs d'université : le cas du concours d'agrégation du supérieur en sciences de gestion' (2013) 142 Revue Française d'Administration Publique (RFAP) 399.

78 Michel Grimaldi, 'Pour que vive le concours d'agrégation en droit!' (2014) 3 Recueil Dalloz Sirey 152; Muriel Fabre-Magnan, 'La réforme du statut des universitaires' (2014) 38 Recueil Dalloz Sirey 2232; Olivier Beaud, 'Libres propos sur le concours d'agrégation du supérieur' (2015) 16 Actualité Juridique Droit Administratif (AJDA) 920; André Legrand, 'Un toilettage du statut des enseignants-chercheurs, mais pas une révolution' (2014) 40 Actualité Juridique Droit Administratif (AJDA) 2304; Benjamin Moron-Puech, 'État des lieux et propositions nouvelles pour une évolution du concours d'agrégation de l'enseignement supérieur' (2016) 12 Revue de droit d'Assas 37. 
and takes several months, because it comprises several tests. ${ }^{79}$ But only the first of these really depends on the qualitative evaluation of candidates' research. The first test is an interview of each candidate by a panel of seven, two of whom have studied the dossier in depth as rapporteurs. The interview lasts 30 minutes and relates to the candidate's scholarly output, restricted to four items, including the $\mathrm{PhD}$ thesis. When the panel has interviewed all the candidates, it decides who will remain in competition. This first stage is a pre-qualification known as sous-admissibilité.

The other tests in the competition consist of 'lessons' ${ }^{80}$ The test for qualification (admissibilité) is a 30-minute lesson commenting on a text (e.g. statute, regulation, award) prepared in a closed library at the location where the competition is organized (the 'loge'). The tests for admission are a 45-minute lesson followed by a 15-minute discussion with the panel on a general subject after 24 hours of free preparation with a team of assistants; and a 30-minute lesson on a theoretical subject after eight hours' preparation in the loge. These lessons rely on the candidates' legal culture and methodology, but do not reflect their research - unlike the previous stage, which is specifically designed to evaluate this. Statistically, only half of the candidates pass the pre-qualification stage. ${ }^{81}$

Conversely, the other ways of acceding to full professor status seem to give precedence to qualitative peer review of applicants' legal publications - especially because they involve the CNU..$^{82}$ There are two procedures, with different conditions as to length of service, which are similar to the procedure for becoming an associate professor (see sections 4.2. and 6.1) insofar as they involve two steps: nationally, the applicants are qualified for the position of full professor; and locally, they are recruited by selection committees in universities offering positions. The difference from the procedure for associate

79 'Les enseignants-chercheurs: les concours nationaux d'agrégation', accessed May 2017 at www.enseignementsup-recherche.gouv.fr/cid22721/les-concours -nationaux-d-agregation.html.

${ }_{80}$ There are specific features in the three examinations for private law and criminal sciences, public law and history of law and institutions. However, all are structured in the same way: a pre-qualification test on research work, a qualification test in the form of a lesson and two final admission tests - one 'in camera' and one with 24 hours' preparation. It is rather the specificities of the public law examination that are presented here.

${ }^{81}$ 'Les enseignants-chercheurs: les concours nationaux d'agrégation' (n 75): see the reports by the examining board chairs in each discipline.

82 There used to be a second agrégation examination, but it was abolished in 2014: Décret $n^{\circ}$ 2014-997 du 2 septembre 2014 modifiant le décret $n^{\circ} 84-431$ du 6 juin 1984 fixant les dispositions statutaires communes applicables aux enseignants-chercheurs et portant statut particulier du corps des professeurs des universités et du corps des maîtres de conférences JORF n`0204 4 septembre 2014. 
professors is that only full professors can study the applications at the CNU stage or in the selection committees, which results from the constitutional principle that professors are independent. ${ }^{83}$ The common point for both is the importance of legal publications - especially for the CNU's examination of applications, since the rapporteurs read the research forwarded by the applicants whose academic career began some years earlier.

These procedures require applicants to have a qualification higher than the doctorate diploma: the accreditation to supervise research (habilitation $a$ diriger des recherches) ${ }^{84}$ These procedures are similar to those in disciplines other than law. However, the accreditation is all too often, in legal disciplines, a compilation by the candidate of past law publications rather than an original monograph, in contrast to the $\mathrm{PhD}$ thesis; this may change in the future, because the divisions of the CNU are starting to require from applicants an original research work, such as a second thesis. ${ }^{85}$

\subsection{Internal promotions in the course of an academic career}

Associate professors fall into two rankings - classe normale (junior) and hors classe (senior); and full professors into three rankings - '2nd class', '1st class' and 'exceptional class'. The rankings are then subdivided into grades. Teacher-researcher promotion by changing grade is automatic by length of service, except for the exceptional class of full professors, for which there is a selective competition, as there is for changing ranking.

To move up to a higher ranking - and the final grade for full professors - teacher-researchers may, if they wish, undergo a promotion procedure consisting of advancement by choice. Half of the promotions are made nationally, involving the CNU, and half locally in the universities themselves. ${ }^{86}$ In both

83 Conseil d'Etat, 4 / 6 SSR, du 22 mars 2000, 195638 195639, publié au recueil Lebon; Carole Moniolle, 'Prime d'encadrement doctoral et indépendance des professeurs du supérieur' (2000) 5 Actualité Juridique Fonctions Publiques (AJFP) 9.

84 Hélène Pauliat, ' $L$ 'inscription en habilitation à diriger des recherches: l'appréciation encadrée sur la valeur scientifique du candidat' (2012) 23 JCP A (Administrations et collectivités territoriales) 23; Thierry Tauran, 'La recherche en droit, en tant qu'activité créatrice de connaissances' (2005) 2005/2 Revue de la recherche juridique. Droit prospectif 577.

85 CNU, section 01 (droit privé) (n 47); CNU, section 02 (droit public) (n 47); CNU, section 03 (histoire du droit) (n 47).

${ }^{86}$ Décret $n^{\circ} 84-431$ du 6 juin 1984 fixant les dispositions statutaires communes applicables aux enseignants-chercheurs et portant statut particulier du corps des professeurs des universités et du corps des maîtres de conférences (n 70) art 40 (MCF) 56 (PR); Décret $n^{\circ}$ 2017-854 du 9 mai 2017 modifiant le décret $n^{\circ}$ 84-431 du 6 juin 1984 modifié fixant les dispositions statutaires communes applicables aux 
cases 'advancement is based on criteria made public ${ }^{87}$ by the $\mathrm{CNU}$ divisions or university authorities.

By way of illustration, the private law and criminal science division emphasizes the following topics: 'publications', 'research supervision and leadership', and 'reputation', 'teaching activities' and 'collective responsibilities' ${ }^{88}$ Likewise, in the public law division, the topics are 'publications', 'scholarly responsibilities', 'thesis supervision', 'teaching activities', 'administrative responsibilities' and 'national or international responsibilities' ${ }^{89}$ The history of law and institutions division is also eager to see 'scholarly activities' (publications, scholarly responsibilities, thesis supervision), 'teaching activities' and 'collective responsibilities'. ${ }^{90}$

For appraisal by the CNU and the university authorities (academic council limited to teacher-researchers), the procedures involve rapporteurs, who study the applications meticulously, but without the applicants needing to submit their research work. Contrary to what happens for recruiting teacher-researchers, the rapporteurs confine themselves to a dossier presenting the publications, without having to study and assess them.

Consequently, promotions within the academic career are made on the basis of qualitative criteria, especially at the national level; but nonetheless the quality of legal publication is not examined in depth. The same is true for teacher-researcher pay.

\subsection{Evaluation with respect to teacher-researcher pay}

In France, teacher-researchers are public-sector employees. Their pay is therefore uniform: equal grades mean equal pay. Unlike other corps in the public sector, associate and full professors receive very few bonuses on top of their pay. Alongside bonuses for teaching activities, there is very broadly a bonus for research and higher education paid to teacher-researchers who fulfil their

enseignants-chercheurs et portant statut particulier du corps des professeurs des universités et du corps des maitres de conférences (n 70).

87 Décret $n^{\circ} 84-431$ du 6 juin 1984 fixant les dispositions statutaires communes applicables aux enseignants-chercheurs et portant statut particulier du corps des professeurs des universités et du corps des maîtres de conférences (n 70).

${ }_{88}$ 'Conseils Généraux - Portail', accessed May 2017 at www.cpcnu.fr/web/cnu -section-01/conseils-generaux 1.

89 'Conseils Généraux - Portail', accessed May 2017 at www.cpenu.fr/web/cnu -section-02/conseils-generaux 1 .

90 'Conseils Généraux - Portail', accessed May 2017 at www.cpcnu.fr/web/cnu -section-03/conseils-generaux1. 
obligations. ${ }^{91}$ The only bonus that is genuinely indexed on the evaluation of scholarly publications is the 'doctoral supervision and research bonus' (prime d'encadrement doctoral et de recherché (PEDR)). ${ }^{92}$

The PEDR is paid to teacher-researchers for four years. It is attributed either by decision of the CNU or by experts from outside the universities, with the latter having the final say. When the CNU takes the matter in hand, it will make known the criteria by which it examines PEDR applications. Logically, these criteria relate especially to the quality of the applicant's research: publications and scholarly output, doctoral and scholarly supervision (number of current doctors and thesis defences), scholarly diffusion and scholarly responsibilities. ${ }^{93}$ However, as with promotions, CNU rapporteurs or ad hoc experts examine only dossiers, not the actual publications themselves.

\subsection{Difficulty in generalizing the evaluation of teacher-research law publications}

Apart from the instances in which they willingly request a promotion or a bonus, and thus submit to an evaluation procedure of their scholarly publications, teacher-researchers can escape any individual assessment once recruited. To address this position, a 'career monitoring' procedure has been introduced for all teacher-researchers at least once every five years, ${ }^{94}$ unless they apply for a promotion or bonus. ${ }^{95}$

91 Décret n०89-775 du 23 octobre 1989 relatif à la prime de recherche et d'enseignement supérieur des personnels de l'enseignement supérieur relevant du ministère chargé de l'enseignement supérieur 1989 (89-775).

92 Décret $n^{\circ} 2009-851$ du 8 juillet 2009 relatif à la prime d'encadrement doctoral et de recherche attribuée à certains personnels de l'enseignement supérieur et de la recherche 2009 (2009-851).

93 'Conseils Généraux - PEDR', accessed May 2017 at www.cpcnu.fr/web/ cnu-section-01/conseils-generaux2; 'Conseils Généraux - PEDR', accessed May 2017 at www.cpcnu.fr/web/cnu-section-02/conseils-generaux; 'Conseils Généraux - PEDR'<http://www.cpcnu.fr/web/cnu-section-03/conseils-generaux> accessed 28 May 2017.

94 Décret $n^{\circ} 84-431$ du 6 juin 1984 fixant les dispositions statutaires communes applicables aux enseignants-chercheurs et portant statut particulier $d u$ corps des professeurs des universités et du corps des maîtres de conférences (n 70) arts 7-1, 18-1; Décret $n^{\circ}$ 2014-997 du 2 septembre 2014 modifiant le décret $n^{\circ} 84-431$ du 6 juin 1984 fixant les dispositions statutaires communes applicables aux enseignants-chercheurs et portant statut particulier du corps des professeurs des universités et du corps des maîtres de conférences (n 78).

95 Didier Truchet, 'Réforme du statut des universitaires : l'agrégation et le reste. A propos du décret du 2 septembre 2014' (2014) 40 JCP G Semaine Juridique (édition générale) 1724. 
The teacher-researchers involved must draw up a report of all their teaching and research activities. The universities must forward these reports to the relevant CNU divisions for examination. The CNU must then send an opinion to the universities about the careers of the teacher-researchers concerned, which may make recommendations to the extent that 'the institutions take this career monitoring into consideration in terms of professional support' ${ }^{96}$

Overall, the CNU divisions have been very reluctant to carry out this new mission, believing that they already undertake many peer reviews. For example, in February 2016 the private law division unanimously passed a motion objecting to the introduction of the new procedure. ${ }^{97}$ In the absence of any opinion from the $\mathrm{CNU}$ division, it is difficult to measure the viability of the career monitoring procedure. In any event, this procedure suffers from the same failings as those for granting promotions and bonuses, since here again, research is not really evaluated.

\section{CONCLUSION}

In conclusion, the evaluation of academic legal publications in France is more important to commence an academic career than to progress in it. This is probably regrettable and the situation may change in the future, as young generations are more open to assessment than their elders.

The evaluation criteria are increasingly made public and transparent by the institutions of evaluation (HCERES, universities, CNU, ANR); but this does not mean that they are really operational, as the practice is often stronger than the theory. To express objective and transparent qualitative criteria is not, unfortunately, incompatible with the opaque preservation of old practices of favouritism, which is difficult to measure. It may be heavily criticized, but only a change in the mentalities of academic staff can overcome this.

Other critics point to the cumbersome academic procedures, the financial dependence of the state and the opacity of legal publishers, which are more interested by money than by science. Once again, only a change in mentalities can drive a change of practices, especially as the normative and institutional evolution has not yet led to the expected results. Further, the revalorization of legal research by public policies may be positive, but it needs a political intent.

Qualitative peer review of law publications is gaining ground in French universities; but it is still not general practice. Besides, care must be taken not

96 Décret $n^{\circ} 84-431$ du 6 juin 1984 fixant les dispositions statutaires communes applicables aux enseignants-chercheurs et portant statut particulier du corps des professeurs des universités et du corps des maîtres de conférences (n 70) art 18-1.

${ }_{97}$ 'Recommandations - suivi de carrière', accessed May 2017 at www.cpcnu.fr/ web/cnu-section-01/recommandations-aux-candidats2. 
to fall foul of several traps with a generalized evaluation procedure: the risk of conflict of interest and partiality by reviewers with respect to those being reviewed, the risk of favouring mainstream or fashionable interests and so on. In addition, evaluation may run up against principles of teacher-researcher independence or freedom of expression, which are constitutionally guaranteed. The education code states: 'Teacher-researchers, teachers and researchers enjoy full independence and freedom of expression in the exercise of their teaching functions and research activities, subject to the reserves imposed on them by university traditions and the provisions of the present code, and by principles of tolerance and objectivity. ${ }^{, 98}$

\section{BIBLIOGRAPHY}

Balme P et al, L'université Française : Une Nouvelle Autonomie, Un Nouveau Management (Presses universitaires de Grenoble 2012)

Beaud O, 'Libres Propos Sur Le Concours D'agrégation Du Supérieur' (2015) 16 Actualité Juridique Droit Administratif (AJDA) 920

Buratti L, 'La Cour Des Comptes Juge L'insertion Professionnelle Des Docteurs Décevante' Le Monde (23 March 2016), accessed May 2017 at www.lemonde.fr/campus/article/2016/03/23/la-cour-des-comptes-juge-le -taux-de-chomage-des-docteurs-decevant_4888742_4401467.html

Cour des comptes, 'L'insertion Professionnelle Des Jeunes Docteurs' (2016) Référé $n^{\circ} \mathrm{S} 2015-1294$

Deroussin D, 'Réforme Du Doctorat : Quelles Perspectives ?' (2016) 27 Recueil Dalloz Sirey 1640

Fabre-Magnan M, 'La Réforme Du Statut Des Universitaires' (2014) 38 Recueil Dalloz Sirey 2232

Grimaldi M, 'Pour Que Vive Le Concours D'agrégation En Droit!' (2014) 3 Recueil Dalloz Sirey 152

Koubi G, 'Liste de Revues Droit Au Sens de l'AERES... sans Mention "scientifique”, accessed May 2017 at https://koubi.fr/spip.php?article472

Legrand A, 'Un Toilettage Du Statut Des Enseignants-Chercheurs, Mais Pas Une Révolution' (2014) 40 Actualité Juridique Droit Administratif (AJDA) 2304

Melleray F, 'A La Recherche Des Jurys de Recrutement Des Enseignants-Chercheurs' (2011) 10 Actualité Juridique Droit Administratif (AJDA) 539

Moniolle C, 'Prime D'encadrement Doctoral et Indépendance Des Professeurs Du Supérieur' (2000) 5 Actualité Juridique Fonctions Publiques (AJFP) 9

98 Code de l'éducation, art L952-2. 
Moron-Puech B, 'État Des Lieux et Propositions Nouvelles Pour Une Évolution Du Concours D'agrégation de L'enseignement Supérieur' (2016) 12 Revue de droit d'Assas 37

Pauliat H, 'L'inscription En Habilitation À Diriger Des Recherches : L'appréciation Encadrée Sur La Valeur Scientifique Du Candidat' (2012) 23 JCP A (Administrations et collectivités territoriales) 23

Pigeyre F, 'Recruter Les Professeurs D'université : Le Cas Du Concours D'agrégation Du Supérieur En Sciences de Gestion' (2013) 142 Revue Française d'Administration Publique (RFAP) 399

Renaudie M, 'Entre Critique Juridique et Critique Du Droit. Retour Sur L'analyse Doctrinale Des Réformes Universitaires Françaises' 2016 Revue de la recherche juridique - Droit prospectif 13

RomiR, 'LesNouvellesModalitésdeRecrutementDesEnseignants-Chercheurs : Une Réforme À Parfaire? ' (2009) 4 Actualité Juridique Droit Administratif (AJDA) 192

Tauran T, 'La Recherche En Droit, En Tant Qu'activité Créatrice de Connaissances' (2005) 2005/2 Revue de la recherche juridique. Droit prospectif 577

Truchet D, 'Réforme Du Statut Des Universitaires : L'agrégation et Le Reste. A Propos Du Décret Du 2 Septembre 2014' (2014) 40 JCP G Semaine Juridique (édition générale) 1724 